Aspirasi: Jurnal Masalah-Masalah Sosial | Volume 9, No, 2 Desember 2018

ISSN: 2086-6305 (print) ISSN: 2614-5863 (electronic)

DOI: https://doi.org/10.22212/aspirasi.v7il.1084

link online: http://jurnal.dpr.go.id/index.php/aspirasi/index

\title{
EFEKTIVITAS PENGUKURAN KOMPETENSI GURU
}

\author{
The Effectiveness of Teacher Competency Measurement
}

\author{
Elga Andina \\ elga.andina@dpr.go.id \\ Pusat Penelitian Badan Keahlian DPR RI \\ Jl. Gatot Subroto Senayan Jakarta
}

Naskah Diterima: 28 September 2018 | Naskah direvisi: 4 Desember 2018 | Naskah diterbitkan: 31 Desember 2018

\begin{abstract}
Competence is the basis for describing teacher quality. Unlike the potential test, competency assessment must snapshot the behavior samples displayed in the work situation. The Teacher and Lecturer Law requires 4 competencies to be possessed by the teacher, namely pedagogic competence, professional competence, personal competence, and social competence. However, the government is only capable of testing pedagogic and professional competencies yet. The writer found that (1) the concept of teacher competence doesn't fit the real cases; and (2) the existing measurement methods are improper. This study challenges the competency concept ruled in the Teacher and Lecturer Law to match the actual needs. Data obtained from interviews and discussions with the government, teacher training institutions, and teachers during the drafting of the academic draft law on the teacher. By analyzing teacher's tasks as educator and administrator, the writer propose 3 competencies needed in next policy: (1) individual; (2) collective; and (3) organizational.
\end{abstract}

Keywords: competence, teacher competency, assessment

\begin{abstract}
Abstrak: Kompetensi merupakan landasan untuk mengetahui gambaran kualitas guru. Berbeda dengan tes potensi, penilaian kompetensi harus memotret sampel perilaku yang ditampilkan pada situasi kerja. Undang-Undang Guru dan Dosen mensyaratkan 4 kompetensi yang perlu dimiliki guru yaitu kompetensi pedagogik, kompetensi profesional, kompetensi kepribadian, dan kompetensi sosial. Namun, pemerintah hanya mampu menguji kompetensi pedagogik dan profesional. Penulis menemukan bahwa (1) konsep kompetensi yang digunakan dalam kebijakan saat ini tidak sesuai dengan kasus nyata; dan (2) metode pengukuran saat ini yang tidak tepat. Penelitian ini menantang konsep kompetensi yang diatur dalam Undang-Undang Guru dan Dosen untuk mencocokkan kebutuhan yang sebenarnya. Data diperoleh dari wawancara dan diskusi dengan pemerintah, lembaga pendidikan tenaga kependidikan (LPTK), dan guru selama penyusunan naskah akademik rancangan undang-undang tentang guru. Dengan menganalisis tugas guru sebagai pendidik dan administrator, maka penulis mengusulkan 3 kompetensi yang dibutuhkan dalam kebijakan berikutnya yaitu kompetensi: (1) individu; (2) kolektif; dan (3) organisasional.
\end{abstract}

Kata kunci: kompetensi, kompetensi guru, pengukuran 


\section{Pendahuluan}

Di Indonesia, profesi guru merupakan pekerjaan yang menarik. Hal ini berimplikasi pada meningkatnya peminat LPTK (Lembaga Pendidikan Tenaga Kependidikan) dan jumlah lulusannya. Hampir 1/3 lulusan pendidikan tinggi yang masuk ke angkatan kerja adalah lulusan LPTK (Kementerian Pendidikan dan Kebudayaan, The World Bank, \& Australian Aid, 2014:3). Akan tetapi, jumlah tersebut belum selaras dengan kualitasnya. Kompetensi guru masih menjadi tugas rumah yang perlu ditingkatkan.

Pada uji kompetensi awal yang dilakukan pada 275.768 guru tingkat nasional cukup memprihatinkan. Dari bobot skor 100, ternyata nilai terendah dari hasil uji tersebut adalah 1, dan rata-rata skornya adalah 41,5. Ini mengindikasikan bahwa kompetensi guru masih rendah berdasarkan tolok ukur yang ditentukan dalam standar pendidik dan tenaga kependidikan. Selanjutnya, di tahun 2015 dilaksanakan uji kompetensi guru, yang ternyata menemukan nilai rata-rata kompetensi guru nasional hanya mencapai skor 56,69. Hasil uji kompetensi ini memperlihatkan perbedaan hasil uji kompetensi antara guru yang sudah S-1 dengan guru yang belum S-1. Untuk Taman Kanak-kanak (TK) rata-rata nilainya adalah 59,65 . Untuk guru SD yang datanya paling banyak belum memenuhi S-1 mendapatkan rata-rata nilai 54,33, untuk jenjang SMP rata-ratanya 58,25 ; dan untuk SMA rataratanya 61,71 . Nilai ini tentu membingungkan karena selama ini guru telah mengajar di dalam kelas selama bertahun-tahun. Jika mengacu pada nilai di atas saja, kita mendapatkan kesan bahwa kebanyakan guru tidak kompeten dalam menjalankan tugasnya. Padahal, guru yang kompeten merupakan kunci pendidikan yang efektif.

Kompetensi lebih dari sekadar pengetahuan dan keterampilan. Ini melibatkan kemampuan untuk memenuhi tuntutan kompleks, dengan memanfaatkan dan memobilisasi sumber daya psikososial (termasuk keterampilan dan sikap) dalam konteks tertentu (OECD, 2003:4). Secara sederhana kompetensi dapat dimaknai sebagai "sesuatu yang benar-benar dilakukan seseorang dan dapat diobservasi" (Bartram, Robertson, \& Callinan, 2002, dalam Guillén \& Saris, 2013:66). Kompetensi guru yang dituntut Undang Undang No 14 Tahun 2005 tentang Guru dan Dosen (UUGD) didefinisikan sebagai seperangkat pengetahuan, keterampilan, dan perilaku yang harus dimiliki, dihayati, dan dikuasai oleh guru atau dosen dalam melaksanakan tugas keprofesionalan.

Sebenarnya, skor kompetensi yang dirilis Kementerian Pendidikan dan Kebudayaan (Kemendikbud) belum bisa menggambarkan keadaan guru secara komprehensif, karena uji kompetensi yang diselenggarakan Kemendikbud belum meliputi keseluruhan kompetensi yang disyaratkan oleh UUGD (kompetensi pedagogik, kompetensi profesional, kompetensi, kepribadian, dan kompetensi sosial), yaitu hanya menguji kompetensi pedagogik dan profesional. Akibatnya, skor uji kompetensi tidak dapat menjadi acuan kualitas guru yang ada, sebab banyak guru yang telah melaksanakan tugas mengajar selama bertahun-tahun. Menjadi tidak adil jika tiba-tiba kinerja guru terhapus dan diganti dengan skor buruk kompetensi. Apalagi ujian kompetensi yang dilakukan dengan tes tertulis, sehingga menimbulkan pertanyaan seberapa efektif tes ini memprediksi kompetensi guru. Akibatnya Pemerintah juga tidak dapat membedakan antara guru yang kompeten dan yang tidak, karena tidak semua guru kompeten berhasil dalam ujian kompetensi, dan sebaliknya.

Kondisi di atas menunjukkan adanya permasalahan dalam pengujian kompetensi guru. Permasalahan kompetensi guru sebenarnya sudah banyak diuji semenjak disahkannya UUGD. Akan tetapi, berbagai penelitian mengenai kompetensi guru terbatas mengenai dampak kompetensi terhadap kualitas pengajaran (Sobandi, 2010) dan peningkatan prestasi siswa (Novauli, 2012; Azzahra, 2015; Inayah, Martono, \& Sawiji, 2013; Sutardi, 2016). Namun, belum ada yang mempertanyakan konsep pengukuran kompetensi guru itu sendiri. Oleh karena itu, penelitian ini ingin mengetahui bagaimana efektivitas pengukuran kompetensi guru? 
Penelitian kualitatif ini menggunakan pendekatan fenomenologi. Pengumpulan data dilakukan pada bulan Juli hingga Oktober 2018. Pengumpulan data dimulai dengan data sekunder yang dirangkum dari review literatur secara sistematik mengenai kompetensi guru di berbagai negara dari jurnal dan buku. Sementara itu, data primer didapatkan melalui wawancara dan diskusi dengan pertanyaan terbuka, mengenai: Bagaimana pendapat saudara mengenai pengaturan kompetensi guru saat ini? Responden penelitian ini antara lain:

1. Organisasi Profesi, yang terdiri dari: (a) Persatuan Guru Republik Indonesia (PGRI); dan (b) Ikatan Guru Indonesia (IGI)

2. Kementerian Pendidikan dan Kebudayaan; beserta Dinas Pendidikan Provinsi Jawa Barat; Dinas Pendidikan Provinsi Kalimantan Barat, dan Dinas Pendidikan Kabupaten Belitung.

3. Kementerian Agama;

4. Guru di Musyawarah Guru Mata Pelajaran Sejarah DKI Jakarta, Musyawarah Guru Mata Pelajaran Kalimantan Barat, Guru SMA N 1 Tanjung Pandan.

5. LPTK, diantaranya (a) Universitas Pendidikan Indonesia; (b) FKIP Universitas Tanjungpura; dan (c) Universitas Pendidikan Muhammadiyah Sorong.

Untuk mengetahui kondisi implementasi pengelolaan kompetensi di daerah, dilakukan pengambilan data ke 4 provinsi: Jawa Barat, Kalimantan Barat, Papua Barat, dan Bangka Belitung. Pemilihan lokasi didasarkan dari saran Kemendikbud di mana 4 daerah tersebut memiliki variasi kualitas pendidikan, sehingga diharapkan peneliti dapat menggambarkan kondisi kompetensi guru secara luas. Kedua data dianalisis secara tematik, yaitu dengan mengelompokkan temuan-temuan yang sejenis untuk mendapatkan kesimpulan. Peneliti mengklasifikasikan temuan yang terkait: (1) pendapat subjek mengenai konstruk kompetensi yang ada sekarang; dan (2) saran mengenai pengukuran kompetensi yang sebaiknya digunakan. Hasil kajian diharapkan dapat menjadi masukan dalam kajian revisi Undang-Undang No 14 Tahun 2005 tentang Guru, terutama dalam substansi kompetensi agar didapat konsep kompetensi yang tepat guna.

\section{Tentang Kompetensi}

David McClelland adalah guru manajemen pertama yang menggunakan istilah "kompetensi" pada tahun 1953 (Chouhan \& Srivastava, 2014:14). Pada masa itu Amerika mengandalkan tes intelegensi dan aptitude di sekolah, universitas dan dunia kerja. Profesor Psikologi Universitas Harvard itu mempertanyakan bagaimana mungkin tes intelegensi dan aptitude memadai untuk memprediksikan "layak" dan "tidak layak"nya seseorang untuk sebuah pekerjaan pembelajaran (McClelland, 1973:1). Ia menemukan skor kedua tes tersebut tidak dapat membedakan orang-orang dari kelas pendidikan dan pekerjaan berbeda. McClelland pun menyadari bahwa korelasi antara skor tes intelegensi dan kesuksesan kerja seringkali tidak kuat (McClelland, 1973:3). Oleh karena itu, dimulailah pengukuran terhadap perilaku yang menunjukkan kecakapan dalam bekerja (kompeten).

Dalam buku Competence at Work, Spencer \& Spencer (1993) menjelaskan pengertian kompetensi sebagai an underlying characteristic of an individual that is causally related to criterion referenced effective and/or superior performance in a job or situation. karakteristik yang dimiliki individu yang berkaitan dengan kinerja efektif dan/atau unggul dalam suatu pekerjaan atau situasi. Sementara itu, Retour (2012, dalam Libanio, Amaral, \& Migowski, 2017: 196) menganggap kompetensi sebagai keterampilan operasional tahu-bagaimana yang sudah divalidasikan. Kompetensi dibutuhkan agar seseorang agar dapat melaksanakan tugas secara efektif dan sukses. Namun, secara filosofis, kompetensi tidak sama dengan pekerjaan. Meskipun memang kompetensi dan pekerjaan memiliki keterkaitan yang sangat erat. Kompetensi dalam konteks ini lebih cenderung merupakan prasyarat tertentu yang harus dipenuhi oleh seseorang sebelum melakukan suatu pekerjaan (Soemantri, 2010:685). Konsep ini sejalan dengan ide McClelland, yang menyatakan kompetensi spesifik pada tugas dan organisasi, sehingga mereka hanya bisa digambarkan dalam konteks pekerjaan yang ditugaskan (Evangelista, 2009:1) 
Mudhofir (2012) menyimpulkan kompetensi itu dipandang sebagai pilarnya atau teras kinerja dari suatu profesi. Hal itu mengandung implikasi bahwa seorang profesional yang kompeten itu harus dapat menunjukkan karakteristik utamanya, antara lain:

1. Mampu melakukan sesuatu pekerjaan tertentu secara rasional. Ini berarti ia memiliki kemampuan analisis kritis dan pertimbangan logis untuk membuat pilihan dan memutuskan.

2. Menguasai perangkat pengetahuan (teori dan konsep, prinsip dan kaidah, hipotesis dan generalisasi, data dan informasi, dsb.) tentang seluk beluk apa yang menjadi bidang tugas pekerjaannya.

3. Menguasai perangkat keterampilan (strategi dan taktik, metode dan teknik, prosedur dan mekanisme, sarana dan instrumen, dsb) tentang cara bagaimana dan dengan apa harus melakukan pekerjaannya.

4. Memahami standar kelayakan normatif minimal kondisi keberhasilan pengajaran

5. Memiliki motivasi dan aspirasi untuk melakukan tugasnya

6. Memiliki kewenangan untuk mendemonstrasikan dan menguji kompetensinya agar memperoleh pengakuan.

Berdasarkan pengertian di atas, kompetensi dalam tulisan ini diartikan sebagai seperangkat keterampilan keras (hard skill) dan keterampilan lunak (soft skill) yang dapat diukur, dibutuhkan untuk dapat menyelesaikan pekerjaan tertentu.

\section{Kompetensi Guru}

Para ahli memiliki beberapa ide mengenai kompetensi yang umumnya dimiliki guru, misalnya kemampuan intelektual; manajemen; keterampilan interpersonal; menjadi profesional (Hong et al, 2008 dalam Ilandou \& Zand, 2011:1144); mampu melakukan kontak secara pantas dengan penonton (Huntley, 2003, dalam Ilandou \& Zand, 2011:1144). Sementara itu, menurut Fathivajargah (2003, dalam Ilandou \& Zand, 2011:1145), guru yang pantas dipekerjakan adalah yang memiliki kompetensi kognitif (kesadaran diri, kesadaran pembelajar, dan kesadaran atas proses belajar mengajar), emosional (berdasarkan minat, nilai, dan sikap), dan praktikal (berkaitan dengan murid, kelas, sekolah, dan masyarakat).

Semakin meningkatnya upaya untuk memperbaiki kualitas pendidikan mendorong penelitian mengenai kompetensi guru terus bertambah. Oleh karena itu daftar kompetensi guru senantiasa diperbarui sejalan dengan perubahan dan tantangan yang dihadapi guru dalam konteks dampak kebijakan pendidikan global (Kovač, Eafajac \& Buchberger, 2014:54). Akhirnya Kovač, Eafajac \& Buchberger (2014:54) mengumpulkan daftar kompetensi guru dan menemukan ada 39 kompetensi yang dibagi atas 4 kelompok, yaitu:

a. Kompetensi terkait nilai-nilai dan pengasuhan anak;

b. Kompetensi yang berkaitan dengan pemahaman sistem pendidikan dan kontribusi terhadap pengembangannya;

c. Kompetensi berkaitan pengetahuan mengenai mata pelajaran, pedagogi, dan kurikulum;

d. Kompetensi terkait evaluasi diri dan pengembangan profesional.

Pada awal penelitian mengenai kompetensi guru, banyak kompetensi sosial yang belum dimasukkan, diantaranya kesediaan guru untuk berpartisipasi dalam debat publik tentang pendidikan; memantau dan berpartisipasi dalam kegiatan amal yang relevan; kemampuan berpartisipasi dalam proyek di bidang pendidikan; memahami prioritas nasional dalam pendidikan; kesediaan untuk bekerja sama dengan masyarakat setempat dalam mengatur kegiatan program (misalnya menyelenggarakan pelatihan praktis dalam bisnis lokal); kemampuan untuk mengantisipasi kebutuhan pasar tenaga kerja baru yang terkait dengan pendidikan; kemampuan melakukan penelitian untuk kemajuan pendidikan; pemahaman tentang legislasi dan otoritas dalam pendidikan; kesediaan untuk bekerja sama dengan pemangku kepentingan dari institusi kesehatan dan sosial; dan kemauan untuk berpartisipasi dalam rencana pengembangan sekolah (Scheerens, 2010, dalam Kovač, Eafajac \& Buchberger, 2014:56).

Penelitian terhadap efektivitas guru di Inggris telah menghasilkan model yang mengaitkan 3 faktor: karakteristik profesional, keterampilan 
mengajar, dan iklim kelas (Sammons \& Bakkum,2011:16). Sementara itu, menurut Aghaie (dalam Ilandou \& Zand, 2011:1145) para guru perlu memiliki kompetensi (1) pengetahuan atas berbagai keterampilan berpikir dan mengaplikasikannya; (2) familiar dengan metode pembelajaran dan pengajaran baru serta mengaplikasikannya; (3) manajemen kelas dan keterampilan khusus untuk berkomunikasi dengan murid; (4) familiar dengan teknologi komunikasi dan informasi, serta mampu menggunakannya dalam pengajaran; (5) keterampilan meneliti; dan (6) terampil dalam mengevaluasi prestasi akademik. Shabani membagi kompetensi guru secara sederhana, yaitu (1) kompetensi karakteristik, yang meliputi pengaturan berorientasi murid, berorientasi pada murid dan kedekatan murid, dan pengaturan berorientasi subjek; (2) saintifik, yang termasuk di dalamnya adalah kesadaran psikologi, metode mengajar, metode komunikasi baru, psikologi sosial, psikologi pengajaran dan komunikasi (Ilandou \& Zand, 2011:1145). Ahli lain, Taghi Pour Zahir (2010, Ilandou \& Zand, 2011:1145) juga membagi 2 kompetensi guru menjadi vokasional dan personal, di mana vokasional meliputi pengetahuan umum, pengetahuan vokasi dan keterampilan komunikasi; sedangkan yang personal antara lain kesehatan jiwa dan fisik, ketaatan pada nilai, serta memiliki kemampuan mental yang baik.

Ilandou dan Zand (2011:1145) sendiri mengusulkan guru memiliki kompetensi umum dan kompetensi khusus. Kompetensi umum meliputi pemahaman dengan psikologi perkembangan dan pembelajaran, kesadaran akan proses pengajaran-pembelajaran, manajemen kelas, metode pengajaran, pengontrolan dan evaluasi. Sementara itu, kompetensi khusus antara lain penguasaan konten, menyajikan konten dalam urutan yang tepat, mengorganisasi konten, menguasai penggunaan alat latihan, mencatat secara akurat, memberikan umpan balik kepada murid (Ilandou \& Zand, 2011:1145).

Dari uraian di atas tampaknya kompetensi individual tidak cukup jika tidak diaplikasikan untuk tujuan-tujuan kolektif(OECD, 2003), dalam hal ini cita-cita pendidikan nasional. Kemudian, guru sebagai individu juga perlu memperlihatkan performa yang mencerminkan kompetensi institusional. Oleh karena itu, penulis sepakat dengan Libanio, Amaral, \& Migowski (2017) yang membagi kompetensi ke dalam 3 level, yaitu kompetensi personal, kompetensi kolektif, dan organisasional. Meskipun pembagian ini berfokus pada pekerjaan desainer, namun dapat dianalogikan pada profesi guru, yaitu menjadi:

Kompetensi Personal, yaitu pengetahuan dan keterampilan praktis yang ditampilkan dalam perilaku termasuk di dalamnya: bersikap proaktif, kinerja kreatif, karakter entrepreneur, keterampilan, sikap dan nilai seorang pendidik, pemikiran strategis dan sistemik, pengetahuan teknis dan ilmiah, kemampuan kognitif, pengetahuan implisit dan eksplisit dan kompetensi dalam pengajaran.

Kompetensi Kolektif, yaitu kompetensi dalam kelompok, yang ditunjukkan seragam oleh para guru dalam sekolah yang sama. Menurut Davenport dan Prusak (1998, dalam Libanio, Amaral, \& Migowski, 2017: 196) dengan menggabungkan pemikiran individu dalam suatu kelompok dapat menghasilkan ide bagi yang lain. Yang termasuk dalam kompetensi kolektif adalah pembentukan struktur, komunikasi, dan mengintegrasikan individu dan tim kerja, kolaborasi antar anggota tim, membuat jejaring, kombinasi sumber daya internal dan eksternal berbagai informasi dan pengetahuan antar anggota kelompok dan konstruksi proyek bersama yang berfokus pada manajemen kompetensi.

Kompetensi Organisasional. Pentingnya integrasi strategi antar guru-guru yang bertanggung jawab, selasar dalam pikiran, sehingga dapat tercapai tujuan-tujuan organisasi. Kompetensi organisasi berhubungan dengan pengetahuan organisasi yang diterjemahkan dalam kegiatan harian, proses, dan praktik, mengajar dipahami sebagai aktivitas multifungsi dan sentral; kemampuan menempatkan dan mengkoordinasikan kompetensi; kemampuan mengubah, memindahkan, dan menjalankan pengetahuan implisit; memberikan dukungan dan umpan balik kepada manajemen atas hasil kerja 
tim; kapasitas organisasional untuk mendidik; pendidikan merefleksikan nilai-nilai sekolah/ institusi pendidikan; mengembangkan budaya yang terus belajar; proses pembentukan jalan dan penciptaan kreasi; perserikatan organisasi, penciptaan nilai; pembentukan dengan informasi yang baik dan budaya nilai-nilai bersama; budaya organisasi; mengembangkan kemampuan internal dengan orientasi entrepreneur; dan konstruksi berorientasi proyek ingatan berdasarkan kompetensi khusus.

\section{Pengaturan tentang Kompetensi Guru}

Dalam UU GD Kompetensi guru diartikan sebagai seperangkat pengetahuan, keterampilan, dan perilaku yang harus dimiliki, dihayati, dan dikuasai oleh guruatau dosen dalammelaksanakan tugas keprofesionalan. Kompetensi diperoleh melalui pendidikan profesi, yaitu:

1. Kompetensi pedagogik adalah kemampuan yang harus dimiliki guru berkenaan dengan karakteristik siswa dilihat dari berbagai aspek seperti moral, emosional, dan intelektual. Hal tersebut berimplikasi bahwa seorang guru harus mampu menguasai teori belajar dan prinsip-prinsip belajar, karena siswa memiliki karakter, sifat, dan interest yang berbeda. Berkenaan dengan pelaksanaan kurikulum, seorang guru harus mampu mengembangkan kurikulum tingkat satuan pendidikan masing-masing dan disesuaikan dengan kebutuhan lokal. Guru harus mampu mengoptimalkan potensi peserta didik untuk mengaktualisasikan kemampuannya di kelas, dan harus mampu melakukan kegiatan penilaian terhadap kegiatan pembelajaran yang telah dilakukan (Direktorat Tenaga Kependidikan,2008:4). Kemampuan yang harus dimiliki guru berkenaan dengan aspekaspek yang diamati, yaitu (Direktorat Tenaga Kependidikan,2008:4):

a. Penguasaan terhadap karakteristik peserta didik dari aspek fisik, moral, sosial, kultural, emosional dan intelektual.

b. Penguasaan terhadap teori belajar dan prinsip-prinsip pembelajaran yang mendidik.

c. Mampu mengembangkan kurikulum yang terkait dengan bidang pengembangan yang diampu.

d. Menyelenggarakan kegiatan pengembangan yang mendidik.

e. Memanfaatkan teknologi informasi dan komunikasi untuk kepentingan penyelenggaraan kegiatan pengembangan yang mendidik.

f. Memfasilitasi pengembangan potensi peserta didik untuk mengaktualisasikan berbagai potensi yang dimiliki.

g. Berkomunikasi secara efektif, empatik, dan santun dengan peserta didik.

h. Melakukan penilaian dan evaluasi proses dan hasil belajar, memanfaatkan hasil penilaian dan evaluasi untuk kepentingan pembelajaran.

i. Melakukan tindakan reflektif untuk peningkatan kualitas pembelajaran.

2. Kompetensi kepribadian, adalah kemampuan kepribadian yang mantap, berakhlak mulia, arif, dan berwibawa serta menjadi teladan peserta didik. Pelaksanaan tugas sebagai guru harus didukung oleh suatu perasaan bangga akan tugas yang dipercayakan kepadanya untuk mempersiapkan generasi kualitas masa depan bangsa. Dengan kata lain seorang guru harus memiliki passion yang tercermin dalam tata nilai norma, moral, estetika, dan ilmu pengetahuan yang nantinya memengaruhi perilaku etik siswa sebagai pribadi dan anggota masyarakat. Guru dituntut harus mampu membelajarkan siswanya tentang disiplin diri, belajar membaca, mencintai buku, menghargai waktu, belajar bagaimana cara belajar, mematuhi aturan/tata tertib, dan belajar bagaimana harus berbuat. Semuanya itu akan berhasil apabila guru juga disiplin dalam melaksanakan tugas dan kewajibannya (Direktorat Tenaga Kependidikan,2008:5). Guru harus mempunyai kemampuan yang berkaitan dengan kemantapan dan integritas kepribadian seorang guru. Aspek-aspek yang diamati adalah (Direktorat Tenaga Kependidikan,2008:5-6):

a. Bertindak sesuai dengan norma agama, hukum, sosial, dan kebudayaan nasional Indonesia.

b. Menampilkan diri sebagai pribadi yang jujur, berakhlak mulia, dan teladan bagi peserta didik dan masyarakat.

c. Menampilkan diri sebagai pribadi yang mantap, stabil, dewasa, arif, dan berwibawa.

d. Menunjukan etos kerja, tanggung jawab 
yang tinggi, rasa bangga menjadi guru, dan rasa percaya diri.

e. Menjunjung tinggi kode etik profesi guru.

3. Kompetensi sosial, yaitu kemampuan guru untuk berkomunikasi dan berinteraksi secara efektif dan efisien dengan peserta didik, sesama guru, orangtua/wali peserta didik, dan masyarakat sekitar. Guru di mata masyarakat dan siswa merupakan panutan yang perlu dicontoh dan merupakan suri tauladan dalam kehidupan sehari-hari. Guru perlu memiliki kemampuan sosial dengan masyarakat, dalam rangka pelaksanaan proses pembelajaran yang efektif. Dengan dimilikinya kemampuan tersebut, otomatis hubungan sekolah dengan masyarakat akan berjalan dengan lancar, sehingga jika ada keperluan dengan orang tua siswa, para guru tidak akan mendapat kesulitan. Kemampuan sosial meliputi kemampuan guru dalam berkomunikasi, bekerja sama, bergaul simpatik, dan mempunyai jiwa yang menyenangkan. Kriteria kinerja guru yang harus dilakukan adalah (Direktorat Tenaga Kependidikan,2008:6):

a. Bertindak objektif serta tidak diskriminatif karena pertimbangan jenis kelamin, agama, ras, kondisi fisik, latar belakang keluarga, dan status sosial ekonomi.

b. Berkomunikasi secara efektif, empatik, dan santun dengan sesama pendidik, tenaga kependidikan, orang tua, dan masyarakat.

c. Beradaptasi di tempat bertugas di seluruh wilayah Republik Indonesia yang memiliki keragaman sosial budaya.

d. Berkomunikasi dengan komunitas profesi sendiri dan profesi lain secara lisan dan tulisan atau bentuk lain.

4. Kompetensi profesional, yaitu kemampuan penguasaan materi pelajaran secara luas dan mendalam. Kompetensi Profesional yaitu kemampuan yang harus dimiliki guru dalam perencanaan dan pelaksanaan proses pembelajaran agar dapat mencapai tujuan pembelajaran (Direktorat Tenaga Kependidikan,2008:6-7), untuk itu guru dituntut mampu menyampaikan bahan pelajaran. Guru juga harus adaptif terhadap perubahan dan cepat menangkap informasi terbaru agar mampu menyajikan materi yang aktual.

\section{Pengukuran Kompetensi Saat Ini}

Setidaknya ada 3 aktivitas pengujian yang sama-sama mengukur empat kompetensi yang disebutkan dalam UUGD, yaitu (1) Pendidikan Program Guru yang mensyaratkan tes potensi akademik berikut tes pedagogik, tes bidang studi, dan tes bakat minat; (2) Uji Kompetensi Guru (UKG) yang mengukur kompetensi pedagogik dan profesional bagi guru yang sudah sertifikasi maupun yang belum; dan (3) Penilaian Kinerja Guru (PKG) yang dilakukan 2 kali dalam setahun untuk mengukur kompetensi pedagogik, profesional. kepribadian. dan sosial.
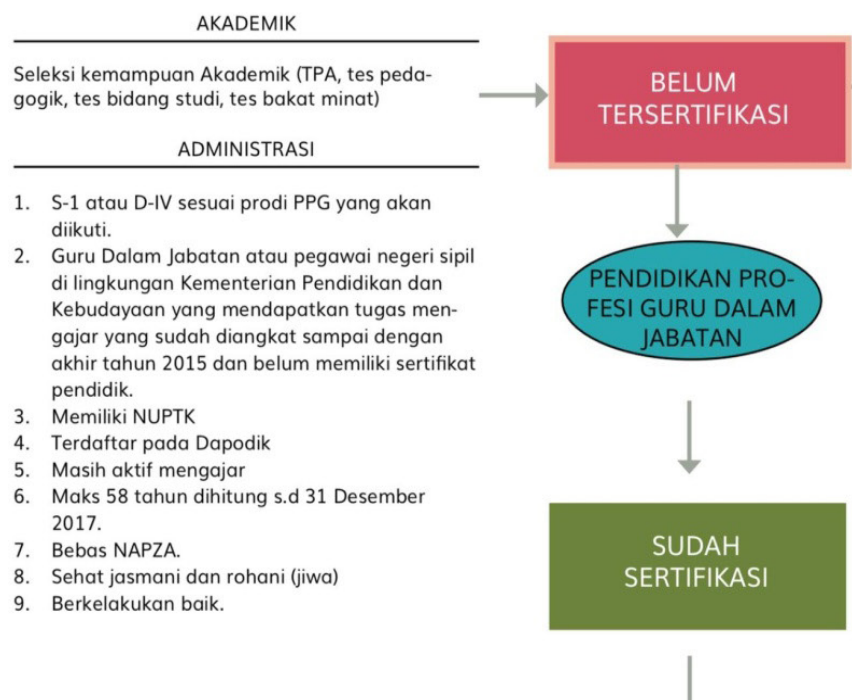
Meskipun mengukur hal yang hampir serupa, output-nya berbeda-beda. PPG berbuah sertifikasi yang berujung pada peningkatan kompensasi moneter. UKG bertujuan untuk mengetahui landasan pengembangan, sedangkan PKG bertujuan untuk menilai kemampuan guru dalam menerapkan semua kompetensi dan keterampilan yang diperlukan dan menghitung angka kredit (Dirjen Peningkatan Mutu Pendidik dan Tenaga Kependidikan, 2010:3).

Pengukuran kompetensi dilakukan sebagai syarat untuk mengikuti Pendidikan Profesi Guru dalam Jabatan (PPGDJ). Namun, program ini lebih bersifat formalitas yang mengutamakan portofolio untuk menerbitkan sertifikasi. Terbukti dari penelitian Istiarini (2012, dalam Prasojo, Wibowo, \& H.2013:41) yang menyimpulkan bahwa sertifikasi guru hanya memiliki dampak positif sebesar 16,8\% terhadap kinerja guru di Kulonprogo. Penelitian tersebut sejalan dengan kajian Susilaningsih \&Siswandari (Prasojo, Wibowo, \&H.2013:41) yang menunjukkan bahwa implementasi kebijakan Sertifikasi Guru hanya 37\% memengaruhi kualitas pengajaran. Yang lebih parah lagi diakui oleh Dinas Pendidikan Provinsi Kalimantan Barat bahwa sampai sekarang belum pernah melakukan evaluasi guru yang sudah memiliki sertifikat pendidikan karena keterbatasan anggaran. Akibatnya, Menteri Keuangan Sri Mulyani melontarkan kritikan terhadap kurangnya kontribusi sertifikasi terhadap kualitas pendidikan kepada Persatuan Guru Republik Indonesia (PGRI) bahwa besarnya tunjangan guru dalam bentuk sertifikasi tidak mencerminkan kualitas pendidik. ${ }^{1}$ Penggunaan kata "sertifikasi" menjadi menyesatkan karena berfungsi untuk tujuan tambahan: bonus remunerasi bagi penghasilan guru. ${ }^{2}$

Kemudian ada yang dinamakan pengukuran kompetensi melalui Uji Kompetensi Guru. Pada tahun 2015, uji kompetensi awal yang dilaksanakan Direktorat Jenderal Guru dan

Sri Mulyani Sindir Tunjangan Guru Besar Tapi Tak Berkualitas, https://bisnis.tempo.co/read/1105459/srimulyani-sindir-tunjangan-guru-besar-tapi-tak-berkualitas, diakses 3 Juni 2018.

2 Teacher-certification-competency-detraction, http://www. thejakartapost.com/news/2015/03/14/teacher-certificationcompetency-detraction.html, diakses tanggal 20 Mei 2018
Tenaga Kependidikan Kemendikbud menemukan bahwa rata-rata nilai uji kompetensi guru nasional adalah 56,69. Jika dilihat lebih jauh, terdapat perbedaan hasil uji kompetensi antara guru yang sudah S-1 dengan guru yang belum S-1. Untuk Taman Kanak-kanak (TK) rata-rata nilainya adalah 59,65. Untuk guru SD yang datanya paling banyak belum memenuhi S-1 mendapatkan ratarata nilai 54,33, untuk jenjang SMP rata-ratanya 58,25 , dan untuk SMA rata-ratanya 61,71. Data tersebut menunjukkan kompetensi guru, terutama pendidikan dasar, masih memprihatinkan.

Padahal, uji kompetensi guru baru mengukur 2 dari 4 kompetensi yang disyaratkan oleh UUGD. Kedua kompetensi ini adalah kompetensi dasar yang didapat dari pendidikan guru, yaitu kompetensi pedagogik dan kompetensi profesional. Kondisi ini perlu dipertanyakan karena belum bisa menggambarkan kompetensi guru seutuhnya, sebagaimana kritikan dari salah satu guru berikut:

"Nah yg ini agak debatable sebab, jika guruguruini tdk kompeten, pertanyaannya apa alat ukurnya? Sudahkah mampu menilai secara komprehensif? Kalau "tdk kompeten" tetapi selama ini justru sdh dimanfaatkan untuk menjaga kewajiban negara mencerdaskan kehidupan bangsa maka sebenarnya guruguru dalam jabatan ini kan kompeten dan sdh pula memenuhi kualifikasi\}" (SPM, MGMP Sejarah DKI Jakarta, 28 Juli 2018)

Asumsi yang dibangun di atas adalah bahwa semua yang sudah mengajar sudah pasti memiliki kompetensi sebagai guru. Akan tetapi, kondisi yang terjadi di lapangan tidak mendukung asumsi di atas. Mari kita ingat kembali penelitian Maharoh (2005) menunjukkan harapan masyarakat agar kinerja guru dalam mengajar dan pengerjaan administrasi di kelas meningkat setelah diberikan sertifikasi. Kondisi ini masih terlihat dalam Analisis Sumber Daya Manusia Pendidikan Dasar dan Menengah 2015/2016 yang dipublikasikan Kementerian Pendidikan dan Kebudayaan (2016:iv) di mana disebutkan kinerja SDM berdasarkan 5 indikator pendidikan menunjukkan bahwa kinerja dikdasmen termasuk kategori kurang dengan nilai 77,69. Sementara, kinerja guru dikdasmen digolongkan pada 
kategori kurang sebesar 76,43. Kinerja SDM SD, SLB, SMP, dan SMK termasuk kurang dengan nilai masing-masing 76,37, 74,96, 79,16 , dan 76,86, sedangkan SMA termasuk kategori pratama dengan nilai sebesar 81,16 (Kementerian Pendidikan dan Kebudayaan, 2016:iv). Kondisi ini menegaskan pernyataan responden Dr. AS yang menyebutkan belum adanya perubahan dan peningkatan kualitas guru yang mendapatkan sertifikasi dalam proses kegiatan belajar mengajar. Dengan begitu, dapat disimpulkan bahwa pemerintah belum mampu mengimplementasikan ketentuan kompetensi dalam UUGD.

\section{Persepsi mengenai Kompetensi Guru}

Untuk mendalami implementasi kompetensi di lapangan, peneliti menanyakan pendapat responden mengenai pengaturan kompetensi guru ini, yang dijabarkan dalam tabel berikut.

Pendapat responden di atas menunjukkan dua pandangan: (1) bahwa pengaturan kompetensi sudah cukup mengikuti UUGD;

Tabel 1. Tanggapan Responden Mengenai Kompetensi Guru

\begin{tabular}{|c|c|}
\hline Instansi & Tanggapan Mengenai Kompetensi Guru \\
\hline \multicolumn{2}{|l|}{ Kemendikbud } \\
\hline $\begin{array}{l}\text { Direktorat Jenderal } \\
\text { Guru dan Tenaga } \\
\text { Kependidikan } \\
\text { Kementerian } \\
\text { Pendidikan dan } \\
\text { Kebudayaan } \\
3 \text { Agustus } 2018\end{array}$ & $\begin{array}{l}\text { Direktur Pembinaan Tenaga Kependidikan Dikdasmen: Guru punya ilmu pedagogiknya, } \\
\text { ada } 4 \text { kompetensi dasarnya. Itu sudah diatur. } \\
\text { Direktur Pembinaan Guru Pendidikan Menengah dan Pendidikan Khusus: } \\
\text { Untuk guru pendidikan paling bawah (paud, sd) harus berkompetensi terbaik. } \\
\text { Motivasi menjadi guru tk itu sedikit. Yang belum ada di sisdiknas adalah pendidikan } \\
\text { keluarga. }\end{array}$ \\
\hline $\begin{array}{l}\text { Dinas Pendidikan } \\
\text { Provinsi Jawa Barat } \\
23 \text { Juli } 2018\end{array}$ & $\begin{array}{l}\text { Seharusnya ada kerjasama sinergis antara LPTK selaku penyelenggara pendidikan profesi } \\
\text { dan dinas pendidikan serta organisasi profesi untuk melihat dan memenuhi kebutuhan } \\
\text { guru yang sesuai dengan kualifikasi dan Kompetensinya. Pemerintah Daerah Provinsi } \\
\text { Jawa Barat berpendapat bahwa kondisi tuntutan dan perkembangan standar kompetensi } \\
\text { mengalami perkembangan yang cepat sekali namun tidak dapat diimbangi dengan } \\
\text { kecepatan regulasi dan kualitas guru sehingga berdampak pada timbulnya persoalan ketika } \\
\text { akan memberlakukan sistem yang mengakomodasi semua kebutuhan, contoh: Zonasi, } \\
\text { Provinsi tidak diberikan kewenangan melatih guru, serta pemenuhan kompetensi keahlian } \\
\text { dalam rangka melakukan revitalisasi. }\end{array}$ \\
\hline $\begin{array}{l}\text { Dinas Pendidikan } \\
\text { Provinsi Kalimantan } \\
\text { Barat } \\
\text { 28 Juli } 2018\end{array}$ & $\begin{array}{l}\text { Apa benar (mengenai) rendahnya kualitas guru? Benar. } \\
\text { Kebijakan yang dikeluarkan pemerintah dirasakan sangat menghambat, karena tidak } \\
\text { dibarengi kegiatan yang mendorong hal itu. }\end{array}$ \\
\hline $\begin{array}{l}\text { Dinas Pendidikan } \\
\text { Kabupaten Belitung. } \\
4 \text { Oktober } 2018\end{array}$ & $\begin{array}{l}\text { Penentuan kompetensi dan pengukuran kompetensi dilakukan oleh Pemerintah Pusat, dinas } \\
\text { hanya menjalankan aturan yang ada. } \\
\text { Seharusnya yang jadi guru: (1) Memadai secara intelektual; dan (2) Memiliki passion. }\end{array}$ \\
\hline Kementerian Agama & $\begin{array}{l}\text { Kompetensi guru sebagaimana diatur UUGD: kompetensi pedagogik; kompetensi } \\
\text { kepribadian; kompetensi sosial; dan kompetensi profesional. }\end{array}$ \\
\hline \multicolumn{2}{|l|}{ LPTK } \\
\hline $\begin{array}{l}\text { UPI } \\
23 \text { Juli } 2018\end{array}$ & $\begin{array}{l}\text { Kompetensi yang diatur dalam UU Guru dan Dosen sangat membingungkan, karena } \\
\text { menyebutkan salah satu kompetensi guru adalah kompetensi profesional yang menguasai } \\
\text { bidang keilmuan (lebih dititikberatkan pada kompetensi pedagogik). Secara konsep bagi } \\
\text { seorang guru kompetensi profesional itu adalah bagaimana guru menguasai kompetensi } \\
\text { akademik/bidang keahlian, pedagogik, pribadi, dan sosial. Untuk itu istilah kompetensi } \\
\text { profesional harus diganti karena kurang tepat, istilahnya dapat diganti dengan istilah } \\
\text { kompetensi akademik atau bidang ilmu. }\end{array}$ \\
\hline
\end{tabular}




\begin{tabular}{|c|c|}
\hline Instansi & Tanggapan Mengenai Kompetensi Guru \\
\hline $\begin{array}{l}\text { Universitas } \\
\text { Tanjungpura } \\
\text { (Dr. Aswandi ) } \\
27 \text { Agustus } 2018\end{array}$ & $\begin{array}{l}\text { Ujian masuk calon mahasiswa LPTK tidak berbeda dengan calon mahasiswa fakultas } \\
\text { lain, sehingga tidak bisa menyaring calon-calon guru yang memiliki kompetensi khusus. } \\
\text { Belum ada standar rekrutmen calon mahasiswa baik untuk pendidikan akademik maupun } \\
\text { pendidikan profesi guru yang bersifat terpadu dan khusus untuk calon guru. Pengukuran } \\
\text { kompetensi guru yang dibutuhkan tidak dapat dilakukan secara optimal. Selama ini Ujian } \\
\text { Kompetensi hanya mengukur kompetensi profesional dan pedagogik, belum pernah } \\
\text { mengukur kompetensi psikologikal dan sosial. Memang, pembagian kompetensi menjadi } 4 \\
\text { sebagaimana yang tercantum dalam UU Guru dan Dosen tidak sesuai dengan kebutuhan } \\
\text { di lapangan. Seharusnya kompetensi seorang guru antara lain: } \\
\text { Guru profesional adalah guru yang memahami materi ajar } \\
\text { Guru profesional paham siapa muridnya. } \\
\text { Melaksanakan pembelajaran yang mendidik } \\
\text { Guru yang tumbuh dan selalu berkembang dalam mendidik secara berkelanjutan (Manusia } \\
\text { yang suka belajar). }\end{array}$ \\
\hline $\begin{array}{l}\text { Universitas } \\
\text { Pendidikan } \\
\text { Muhammadiyah } \\
\text { Sorong } \\
5 \text { September } 2018\end{array}$ & $\begin{array}{l}\text { Terkait dengan empat kompetensi guru yang telah disusun oleh pemerintah yang mencakup } \\
\text { kompetensi pedagogik, kepribadian, sosial, dan professional sudah cukup memenuhi } \\
\text { untuk diri masing-masing dari calon guru. Adapun kemampuan lain yang harus diberikan } \\
\text { kepada calon guru yaitu berupa kemampuan mengelola teknologi untuk menguasai berbagi } \\
\text { informasi. Unimuda dalam hal ini, telah melakukannya dengan menyiapkan mata kuliah } \\
\text { yang berbasis teknologi. }\end{array}$ \\
\hline \multicolumn{2}{|l|}{ Organisasi Profesi } \\
\hline $\begin{array}{l}\text { PGRI } \\
\text { 18 Juli } 2018\end{array}$ & $\begin{array}{l}\text { Kompetensi guru/dosen harus ditambah meliputi kompetensi: kepribadian, sosial, } \\
\text { akademik (penguasaan bidang ilmu), pedagogik, religius, manajerial, teknologi informasi } \\
\text { \& komunikasi, dan bahasa asing. }\end{array}$ \\
\hline $\begin{array}{l}\text { PGRI Pontianak } \\
28 \text { Agustus } 2018\end{array}$ & kompetensi guru yang belum linear \\
\hline $\begin{array}{l}\text { IGI } \\
18 \text { Juli } 2018\end{array}$ & $\begin{array}{l}\text { Profesional adalah pekerjaan atau kegiatan yang dilakukan oleh seseorang dan menjadi } \\
\text { sumber penghasilan kehidupan yang memerlukan kompetensi, yang memenuhi standar } \\
\text { mutu atau norma tertentu serta memerlukan pendidikan dan pelatihan profesi. } \\
\text { Kompetensi guru sebagaimana dimaksud dalam Pasal } 8 \text { meliputi kompetensi pedagogik, } \\
\text { kompetensi kepribadian, kompetensi sosial, dan kompetensi profesional yang diperoleh } \\
\text { melalui pendidikan profesi.(sesuai rumusan UU GD) }\end{array}$ \\
\hline \multicolumn{2}{|l|}{ MGMP } \\
\hline $\begin{array}{l}\text { Drs. SP } \\
\text { (MGMP Sejarah } \\
\text { DKI Jakarta) } \\
3 \text { Oktober } 2018\end{array}$ & $\begin{array}{l}\text { Memang empat kompetensi tsb, dianggap sebagai kompetensi komprehensif yg patut } \\
\text { dimiliki setiap guru. Bukan saja mampu dari sisi akademik (profesional) tetapi juga } \\
\text { memiliki harus memiliki kapasitas secara kepribadian dan sosialnya } \\
\text { Suparman SMAN 2: Dan sbg guru utamanya harus memiliki kapasitas mendidik (kom pedagogik) }\end{array}$ \\
\hline $\begin{array}{l}\text { Musyawarah Guru } \\
\text { Mata Pelajaran } \\
\text { Sejarah Kalimantan } \\
\text { Barat } \\
29 \text { Agustus } 2018\end{array}$ & $\begin{array}{l}\text { Ditengah keterbatasan yang ada dan walaupun mempunyai kendala dalam melakukan } \\
\text { kegiatannya, Forum MGMP tetap mampu meningkatkan kompetensi dan profesionalisme } \\
\text { guru. Program MGMP di tingkat intern satuan pendidikan biasanya terkait dengan } \\
\text { penyusunan perangkat pembelajaran yang meliputi buku kerja, seperti silabus, analisis } \\
\text { indikator pencapaian kompetensi, analisis standar kompetensi lulusan, pemetaan } \\
\text { Kompetensi Inti (KI), Kompetensi Dasar (KD) }\end{array}$ \\
\hline $\begin{array}{l}\text { Kepala Sekolah } \\
\text { SMAN } 1 \text { Tanjung } \\
\text { Pandan, Provinsi } \\
\text { Bangka Belitung } \\
4 \text { Oktober } 2018\end{array}$ & $\begin{array}{l}\text { Ya disinilah, yang sosial ini memang susah ngaturnya. Kan di kami ada indikator namanya, } \\
\text { memang normatif semua. Susah di pengukurannya. Makanya pemerintah di Kementerian } \\
\text { memang bingung ini mau diapakan. } \\
\text { Kalau di tataran konsep kami tidak bisa berbuat banyak. Tidak bisa diukur, iya. Indikator } \\
\text { itu. Kompetensi sosial, coba bagaimana mengukurnya? } \\
\text { Apakah kita akan survei salat berapa kali sehari? Sehari-harinya bagaimana. } \\
\text { Terus satu lagi, ada syarat guru itu "panggilan jiwa" itu penulis beri tanda merah. } \\
\text { Bagaimana ngukurnya panggilan jiwa coba? Selama ini rekrutmen guru tidak pernah ada } \\
\text { panggilan jiwa diukurnya. } \\
\text { Syarat akademik kan gampanglah. Tapi terus bagaimana guru itu harus profesional,nah itu } \\
\text { kan susah juga ngukurnya. Kami yang tua-tua ini kan merasakan susahnya. Kan dulu pada } \\
\text { gak mau jadi guru. Yang sekarang ini pada mau jadi guru karena ada sertifikasi. }\end{array}$ \\
\hline
\end{tabular}


dan (2) pengaturan kompetensi yang ada masih belum tepat/cukup untuk dapat mendorong performa guru. Pihak yang merasa aturan kompetensi guru sudah cukup adalah pemangku kebijakan yaitu Kemendikbud. Pada hakikatnya Kemendikbud telah mengeluarkan berbagai panduan dan rumusan indikator untuk mengukur 4 kompetensi yang ditetapkan UUGD. Hanya saja Direktorat Jenderal Guru dan Tenaga Kependidikan Kemendikbud hingga kini belum dapat mengimplementasikan pengukuran kompetensi sosial dan kepribadian. Di sini kita bisa melihat bahwa ketidakmampuan pemerintah untuk melaksanakan aturan yang dibuatnya telah menjadi hambatan pencapaian tujuan pengaturan itu sendiri.

Pada kenyataannya, pengaturan kompetensi ternyata diidentifikasikan bermasalah di lapangan. Peneliti mengklasifikasikan 2 masalah yang disampaikan oleh responden penelitian ini mengenai pengukuran kompetensi guru, yaitu: mengenai konstruk kompetensi itu sendiri dan mengenai pengukurannya.

\section{Konstruk Kompetensi Guru}

Dari empat kompetensi yang diatur dalam UUGD ternyata ruang lingkupnya masih tumpang tindih. Kritikan dilemparkan oleh Dr. AS yang merasa "pembagian kompetensi menjadi 4 sebagaimana yang tercantum dalam UU Guru dan Dosen tidak sesuai dengan kebutuhan di lapangan”. Menurut UPI, kompetensi yang diatur dalam UU Guru dan Dosen sangat membingungkan, karena menyebutkan salah satu kompetensi guru adalah kompetensi profesional yang menguasai bidang keilmuan (lebih dititikberatkan pada kompetensi pedagogik). Secara konsep bagi seorang guru kompetensi profesional itu adalah bagaimana guru menguasai kompetensi akademik/bidang keahlian, pedagogik, pribadi, dan sosial. Untuk itu istilah kompetensi profesional harus diganti karena kurang tepat, istilahnya dapat diganti dengan istilah kompetensi akademik atau bidang ilmu.

Pendapat UPI ini menguatkan kekeliruan nomenklatur yang tercantum di UU GD. Dalam ketentuan umum, "Profesional adalah pekerjaan atau kegiatan yang dilakukan oleh seseorang dan menjadi sumber penghasilan kehidupan yang memerlukan keahlian, kemahiran, atau kecakapan yang memenuhi standar mutu atau norma tertentu serta memerlukan pendidikan profesi." Oleh karena itu, jika menggunakan istilah yang sama, maka Kompetensi Profesional seharusnya didefinisikan sebagai kemampuan yang dimiliki seseorang dan menjadi sumber penghasilan kehidupan yang memerlukan keahlian, kemahiran, atau kecakapan yang memenuhi standar mutu dan norma tertentu serta memerlukan pendidikan profesi. Namun, UU GD menjelaskan: Yang dimaksud dengan kompetensi profesional adalah kemampuan penguasaan materi pelajaran secara luas dan mendalam, sedangkan dalam pengertian profesional sendiri sudah tercantum keahlian, kemahiran, atau kecakapan yang merupakan dimensi kompetensi. Oleh karena itu, seharusnya pengaturan kompetensi profesional tidak diperlukan.

Sementara itu, Drs. SP menegaskan kompetensi yang paling penting dimiliki oleh guru adalah kompetensi pedagogik. Untuk menunjang kemampuan guru mengajar UNESCO (2011) mendorong kepiawaian dalam menggunakan teknologi informasi dan komunikasi agar guru dapat mengembangkan pembelajaran yang aktual dan menarik. Kompetensi pedagogik bisa dibilang sebagai kompetensi inti yang harus dimiliki setiap guru, yaitu kumpulan perilaku/kapasitas potensial yang mendorong aktifitas efisien atau sebagai standar profesional minum, seringkali ditentukan oleh hukum, yang harus dicapai para profesional (OECD,2003:412). Kompetensi pedagodi merefleksikan kemampuan guru dalam hal kolaborasi, pandangan komprehensif dan kontribusi pengembangan pedagogi untuk pendidikan lebih tinggi (Ryegård, 2010, dalam OECD, 2003:414)

Kompetensi pedagogik diakui sebagai kompetensi utama yang harus dimiliki setiap guru. Saya juga memandang kompetensi pedagogik yang berfokus pada pengetahuan dan teknik pengajaran beririsan dengan kompetensi kepribadian yang menekankan kemampuan 
kepribadian yang mantap untuk mengarahkan peserta didik; juga beririsan dengan kompetensi sosial yang mengedepankan kemampuan komunikasi efektif. Ketiga kompetensi tersebut merupakan penopang kompetensi profesional yang mengharuskan guru dapat mencapai tujuan pembelajaran.

Sementara itu, kompetensi kepribadian dalam UUGD diartikan kemampuan kepribadian yang mantap, berakhlak mulia, arif, dan berwibawa serta menjadi teladan peserta didik. Penguraian definisi ini ambigu karena kepribadian sendiri tidak dijelaskan. Memang, pada hakikatnya kepribadian bukanlah suatu kompetensi. Pengertian kompetensi selalu mencakup kepribadian sebagai pembentuk kompetensi, bukan sebagai kompetensi sendiri. Istilah kepribadian (personality) berasal dari kata latin persona yang berarti “topeng”. Bagi bangsa roma persona berarti bagaimana seseorang tampak pada orang lain" (Hurlock,1976:236). Allport mendefinisikan kepribadian sebagai susunan sistem-sistem psikofisik yang dinamis dalam diri suatu individu yang menentukan penyesuain individu yang unik terhadap lingkungan" (Hurlock,1976:237). Pola kepribadian merupakan jalinan sistem psikofisik yang ada pada seseorang. Ia merupakan hasil pengaruh hereditas dan lingkungan (Hurlock,1976:238). Sistem psikofisik antara lain kebiasaan, sikap, nilai, keyakinan, keadaan emosional, perasaan dan motif yang bersifat psikologis tapi mempunyai dasar fisik dalam kelenjar, saraf, dan keadaan fisik (Hurlock,1976:236). Kepribadian dapat dilihat dari ciri-ciri kepribadian yang diartikan Azjen (2005, dalam Guillén \& Saris,2013:70) sebagai pilihan personal atau kecenderungan untuk melakukan perilaku tertentu. Dengan begitu, kepribadian tidak dapat diobservasi, kecuali jika diterjemahkan dalam perilaku (Judge et al, 2002, dalam Guillén \& Saris,2013:70).

Berikutnya, kompetensi sosial menurut Gür et al (2015:15) merupakan konsep multi fasad yang melibatkan mood motivasi positif yang membutuhkan adaptasi sosial yang berhasil dan perkembangan kesadaran untuk merealisasikan harapan, sebagai tambahan kemampuan sosio emosional, kemampuan kognitif, dan behavioral. Kompetensi sosial merupakan seperangkat perilaku yang dapat dilatih (Boyatzis, 1982; J.Hogan \& Holland, 2003, dalam Guillén \& Saris,2013:69). Kompetensi sosial yang diatur di dalam UUGD tampaknya membatasi pada kemampuan guru untuk berkomunikasi dan berinteraksi secara efektif dan efisien dengan peserta didik, sesama guru, orangtua/wali peserta didik, dan masyarakat sekitar. Dengan kata lain keterampilan berkomunikasi.

Berdasarkan pendapat di atas, penulis melihat pembagian kompetensi dalam UU GD belum memadai. Selain saling beririsan, kompetensi guru yang disebutkan hanya bersifat personal, yang terkait kegiatan belajar mengajarnya saja. Padahal peran guru menurut Priansa (2014, dalam Alawiyah, 2017:24) sangat luas mulai dari membangun karakter bangsa, mencapai tujuan pendidikan, meningkatkan mutu pendidikan, prosespembelajaran,manajemenberbasissekolah, implementasi kurikulum, dan mengoptimalkan potensi sekolah. Keempat kompetensi yang diatur UUGD belum mencerminkan daya untuk menjalankan peran-peran tersebut. Oleh karena itu, penulis menyarankan pembagian kompetensi guru menjadi 3, yaitu:

1. Kompetensi individual, adalah kapasitas melakukan pengajaran, sehingga dibutuhkan keterampilan pedagogik, keterampilan sosial termasuk keterampilan berkomunikasi dengan peserta didik maupun stakeholder pendidikan lain. Dengan mengambil beberapa indikator dari pengaturan sebelumnya, peneliti mengelompokkan yang termasuk kompetensi individual antara lain: (1) Penguasaan materi; (2) Pengembangan kurikulum; (3) keterampilan Penyampaian materi; (4) Pengembangan potensi peserta didik; (5) penilaian dan evaluasi; (6) Komunikasi interpersonal; (7) Motivasi belajar/ motivasi berprestasi; (8) kemauan bekerja keras; (9) passion untuk mendidik; (10) kreativitas; (11) kepercayaan diri; (12) kemampuan menyesuaikan diri; (13) keseimbangan emosional; (14) daya tahan terhadap tekanan; dan (15) integritas.

2. Kompetensi kolektif, terkait dengan kemampuan guru mengembangkan diri 
sebagai pribadi dalam kelompok dan saling meningkatkan kinerja kelompoknya. Tampaknya guru memang profesi yang bekerja sendiri, namun untuk meningkatkan keterampilan personalnya itu guru perlu berkomunikasi dan bekerja sama dengan rekan sejawatnya, misalnya dengan diskusi dan mengikuti kegiatan pembinaan. Yang dapat diklasifikasikan sebagai kompetensi kolektif adalah kolaborasi antar guru dalam menyelesaikan tugas, membuat jejaring, berbagai informasi dan pengetahuan antar anggota kelompok (melalui MGMP, dsb).

3. Kompetensi organisasi. Kompetensi lain yang tampaknya dibutuhkan namun tidak terdefinisikan adalah kompetensi guru sebagai anggota organisasi. Memiliki kompetensi sebagai bagian dari organisasi berkaitan dengan pencapaian organisasi itu sendiri, dalam hal ini sekolah. Di sini peneliti ingin mengedepankan tugas guru bukan hanya sebagai pendidik, tapi juga agen pembelajaran untuk meningkatkan mutu pendidikan nasional. Kovac, Rafajac, dan Buchberger (2014:55) menyarankan bahwa pendidikan guru harus menampilkan elemen yang mengembangkan kompetensi terkait peran sosial guru, pemahaman akan sistem pendidikan dan peraturan pendidikan atau meningkatkan kesadaran mengenai kontribusinya terhadap perkembangan pendidikan. Perspektif ini sejalan dengan harapan untuk mengarahkan profesi guru untuk beradaptasi dengan tantangan kebijakan pendidikan global (Kovac, Rafajac, dan Buchberger, 2014:55). Meskipun dianggap sebagai peran sekunder guru, namun kompetensi ini merupakan bagian yang tidak terpisahkan dalam upaya membentuk profesi guru yang teladan. Karena dalam satuan kompetensi ini berkaitan dengan kerja sama, kolaborasi, dan kepemimpinan (Kovac, Rafajac, dan Buchberger, 2014:56). Hal ini merupakan implementasi dari tugas guru mendidik, karena menurut Sardiman (2005:51) mendidik bukan sekedar memindahkan pengetahuan tapi juga nilai.

\section{Pengukuran Kompetensi Guru}

"Bagaimana cara mengukur kompetensi sosial dan kepribadian?" tanya Kepala Sekolah SMA Negeri 1 Tanjung Pandan di Kabupaten Belitung. Kebingungannya seirama dengan Kepala bidang GTK Dinas Pendidikan Kabupaten yang hanya menunggu pemerintah pusat untuk merumuskan pengujian kompetensi kepribadian dan sosial. Permasalahannya jelas bahwa kedua kompetensi tidak dapat diukur melalui tes tertulis semata. Namun, sementara ini Kemendikbud baru memiliki anggaran dan kemampuan untuk menyelenggarakan penilaian terbatas ini.

Padahal, McClelland (1973, 1998) merumuskan 4 pendekatan sebagai pengukuran kompetensi yang baik: (1) harus dimulai dari eksplorasi langkah-langkah pemikiran dan tindakan terutama yang terkait dengan kriteria - dalam hal ini, lebih efektif untuk posisi eksekutif dan manajerial tingkat tinggi; (b) harus menilai kelompok kriteria keberhasilan dalam kelompok output kehidupan yang penting (misalnya, pekerjaan, kesehatan, keluarga dan kehidupan sosial, pendidikan); (c) kompetensi yang dinilai harus didefinisikan dan dijelaskan dengan cara yang mencerminkan perubahan atau pembelajaran kehidupan; dan (d) cara meningkatkan kompetensi harus dipelajari, dan dibuat eksplisit dan dipublikasikan. Dengan kata lain, penilaian kompetensi harus dilakukan dengan menilai sampel kerjanya.

Beberapa teknik yang sering digunakan untuk melakukan pengukuran kompetensi adalah teknik Behavioral Event Interview (BEI) yang awalnya dibuat oleh Flanagan pada tahun 1954 dan 17 tahun kemudian diselaraskan oleh Dailey, dan digunakan dalam penelitian Boyatzis di tahun 1982 (McClelland, 1998:331). Secara sederhana BEI bertujuan menemukan perbedaan pekerja yang outstanding (unggul) dan yang typical (biasa). Teknik ini digunakan karena orang cenderung lebih mudah mengidentifikasi siapa yang unggul ketimbang apa yang membuat orang itu unggul. Sesungguhnya, BEI hanyalah salah satu teknik dalam metode pengukuran assessment center, teknik lain antara lain role playing, in basket, dan presentasi. Menariknya 


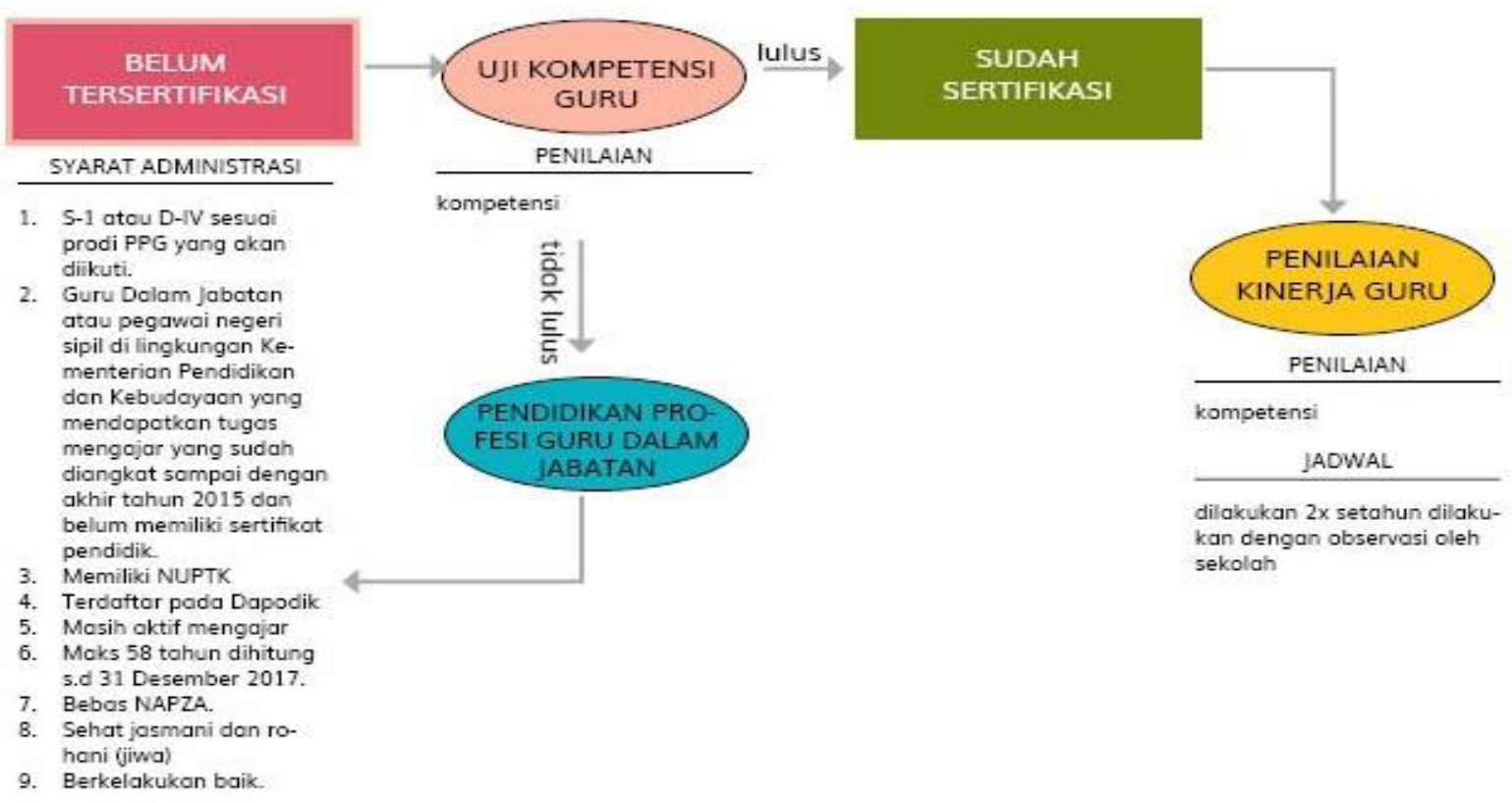

Bagan 2. Usulan Pengukuran Kompetensi Guru

dari assessment center ini adalah pengukuran dilakukan terhadap perilaku yang tampak, bukan hanya potensi sebagaimana yang diprediksi oleh tes intelegensi dan aptitude. Perilaku tampak yang dilaksanakan pada situasi kerja inilah yang kita potret sebagai kompetensi. Dengan begitu, penilaian kompetensi tidak hanya dilakukan dalam tes khusus (assessment center) tapi juga perlu disandingkan dengan observasi harian yang dilakukan oleh kepala sekolah, dengan teknik umpan balik $360^{\circ}$.

Dengan teknik-teknik di atas, pengukuran kompetensi memang membutuhkan anggaran lebih karena tidak sesederhana tes tertulis. Namun, pemerintah dapat melakukan pengukuran yang efisien (lihat Bagan 2).

Beberapa teknik penilaian yang dapat digunakan antara lain:

Tabel 2. Teknik Penilaian Kompetensi

\begin{tabular}{|c|c|c|c|}
\hline Kompetensi & Indikator & Teknik Penilaian & Penguji/Penilai \\
\hline \multicolumn{4}{|l|}{ Pedagogik } \\
\hline Penguasaan materi & Pengetahuan materi & Tes pengetahuan & Dinas \\
\hline Pengembangan kurikulum & Silabus & Portofolio & Dinas \\
\hline Penyampaian materi & Teknik mengajar & Presentasi & \\
\hline $\begin{array}{l}\text { Pengembangan potensi peserta } \\
\text { didik }\end{array}$ & pengarahan kemampuan siswa & BEI & Kepala sekolah, dinas \\
\hline Penilaian dan evaluasi & hasil penilaian akademik & Observasi, portofolio & Kepala sekolah \\
\hline Komunikasi interpersonal & $\begin{array}{l}\text { Cara menyelesaikan konflik } \\
\text { dengan orang lain }\end{array}$ & $\begin{array}{l}\text { Role playing, } \\
\text { observasi }\end{array}$ & $\begin{array}{l}\text { Dinas, assessor, kepala } \\
\text { sekolah }\end{array}$ \\
\hline $\begin{array}{l}\text { Motivasi belajar/ motivasi } \\
\text { berprestasi, }\end{array}$ & $\begin{array}{l}\text { Mengikuti pelatihan/ } \\
\text { pengembangan/pembinaan }\end{array}$ & Portofolio & Dinas, kepala sekolah \\
\hline kemauan bekerja keras & $\begin{array}{l}\text { Bersedia menyelesaikan tugas } \\
\text { secara sungguh-sungguh }\end{array}$ & Observasi & Kepala sekolah \\
\hline passion untuk mendidik & Perilaku di dalam dan luar kelas & BEI, observasi & $\begin{array}{l}\text { Kepala sekolah, assessor, } \\
\text { dinas }\end{array}$ \\
\hline kreativitas & $\begin{array}{l}\text { Solusi untuk menyelesaikan } \\
\text { masalah }\end{array}$ & Presentasi, in basket & assessor \\
\hline kepercayaan diri & $\begin{array}{l}\text { kemampuan menampilkan diri } \\
\text { secara mandiri }\end{array}$ & Presentasi, BEI & dinas \\
\hline kemampuan menyesuaikan diri & $\begin{array}{l}\text { tidak canggung ketika bertemu } \\
\text { orang baru }\end{array}$ & $\begin{array}{l}\text { Observasi, presentasi, } \\
\text { role playing }\end{array}$ & assessor, kepala sekolah \\
\hline
\end{tabular}




\begin{tabular}{|c|c|c|c|}
\hline Kompetensi & Indikator & Teknik Penilaian & Penguji/Penilai \\
\hline keseimbangan emosional & $\begin{array}{l}\text { kemampuan tetap tenang ketika } \\
\text { menghadapi masalah }\end{array}$ & BEI & assessor \\
\hline daya tahan terhadap tekanan & $\begin{array}{l}\text { bertahan terus bekerja meski } \\
\text { dalam waktu yang sempit } \\
\text { mengedepankan dan konsisten }\end{array}$ & Observasi & kepala sekolah, dinas \\
\hline Integritas & $\begin{array}{l}\text { memperlihatkan nilai-nilai } \\
\text { moral }\end{array}$ & Pengamatan & dinas, kepala sekolah \\
\hline \multicolumn{4}{|l|}{ Kolektif } \\
\hline Terlibat dalam kelompok guru & $\begin{array}{l}\text { Mengikuti kegiatan MGMP } \\
\text { Mengikuti seminar-seminar } \\
\text { pengembangan }\end{array}$ & & \\
\hline \multicolumn{4}{|l|}{ Organizational } \\
\hline Pengembangan sekolah & $\begin{array}{l}\text { dalam rencana pengembangan } \\
\text { sekolah }\end{array}$ & observasi & Kepala sekolah \\
\hline Komitmen organisasi & $\begin{array}{l}\text { Mengikuti kegiatan sekolah } \\
\text { Mengikuti kegiatan perlombaan }\end{array}$ & observasi & Kepala sekolah \\
\hline
\end{tabular}

\section{Penutup \\ Simpulan}

UU GD mensyaratkan guru harus memiliki kualifikasi S-1 atau D-IV dan 4 kompetensi, yaitu kompetensi pedagogik, kompetensi profesional, kompetensi kepribadian, dan kompetensi sosial. Akan tetapi, sampai saat ini pemerintah belum dapat melakukan pengukuran terhadap keseluruhan kompetensi tersebut. Oleh karena itu, pada hakikatnya pemerintah belum dapat memenuhi amanah pasal 8 UUGD mengenai kewajiban guru untuk memiliki kualifikasi akademik, kompetensi, sertifikat pendidik, sehat jasmani dan rohani, serta memiliki kemampuan untuk mewujudkan tujuan pendidikan nasional.

Akan tetapi, pengukuran kompetensi guru masih terkendala (1) konsep kompetensi yang belum dapat diimplementasikan pemerintah; dan (2) prosedur pengukuran tidak tepat. Oleh karena itu, perlu ada perbaikan konsep kompetensi guru dari 4 kompetensi pedagogik, profesional, kepribadian, dan sosial menjadi (1) kompetensi individual, (2) kompetensi kolektif dan (3) kompetensi organisasional. Kompetensi individual meliputi keterampilan mengajar seorang guru, termasuk membangun iklim pendidikan yang kondusif dengan pemangku pendidikan lain (orang tua dan masyarakat), sedangkan kompetensi kolektif mencakup kemampuan guru mengembangkan diri dan rekan-rekannya. Kompetensi organisasional dibutuhkan guru sebagai bagian dari organisasi sekolah untuk membangun iklim pendidikan yang berprestasi, termasuk di dalamnya peran sosial guru, pemahaman akan sistem pendidikan dan peraturan pendidikan atau meningkatkan kesadaran mengenai kontribusinya terhadap perkembangan pendidikan.

\section{Saran}

Pengukuran kompetensi harus dilakukan secara efisien namun meliputi keseluruhan kompetensi. Uji Kompetensi harus dijadikan landasan kepemilikan sertifikasi, sehingga dapat menjadi bukti kelayakan seorang pendidik. Sementara itu, penilaian kinerja guru dilakukan oleh sekolah dengan teknik observasi agar dapat memotret kompetensi guru pada kesehariannya.

Penelitian ini hanya dapat memberikan masukan konsep kompetensi umum untuk penyusunan konsep kompetensi dalam perumusan Rancangan Undang-Undang tentang Guru yang sedang dikaji oleh Badan Keahlian DPR RI. Penelitian lanjutan dapat dikembangkan terkait kompetensi khusus yang perlu dikecualikan oleh guru-guru yang berada dalam kondisi geografis tertentu, misalnya daerah tertinggal, terdepan, dan terluar.

\section{Ucapan Terima Kasih}

Penelitian ini didukung oleh dana Penyusunan Rancangan Undang-Undang tentang Guru yang dilaksanakan oleh Pusat Perancangan Undang Undang Badan Keahlian DPR RI. 


\section{DAFTAR PUSTAKA}

\section{Jurnal}

Albanese, M. A., Mejicano, G., Mullan, P., Kokotailo, P., \& Gruppen, L. (2008). "Defining Characteristics of Educational Competencies." Medical Education, 42, 248-255. https://doi. org/10.1111/j.1365-2923.2007.02996.x.

Chouhan, V. S., \& Srivastava, S. (2014). "Understanding Competencies and Competency Modeling-A Literature Survey." IOSR Journal of Business and Management, 16(1), 14-22. https:// doi.org/10.9790/487X-16111422.

Evangelista, L. (2009). "Competence, Competencies and Career Guidance." Coherence, Co-Operation and Quality in Guidance and Counselling Research, $1-6$.

Gür, Ç., Koçak, N., Demircan, A., Uslu, B. B., Şirin, N., \& Şafak, M. (2015). "The Study of 48-60 Month-old Preschool Children's Social Competence and Behavior Evaluation Conditions." Education and Science, 40(180), 13-23. https://doi.org/10.15390/EB.2015.4563.

Guillén, L., \& Saris, W. E. (2013). “Competencies, Personality Traits, and Organizational Rewards of Middle Managers: A Motive-Based Approach.” Human Performance. https://doi.org/10.1080/08 959285.2012.736898.

Ilanlou, M., \& Zand, M. (2011). "Professional Competencies of Teachers and the Qualitative Evaluation." Procedia-Social and Behavioral Sciences, 29, 1143-1150. https://doi. org/10.1016/j.sbspro.2011.11.348.

Inayah, R., Martono, T., \& Sawiji, H. (2013). "Pengaruh Kompetensi Guru, Motivasi Belajar Siswa dan Fasilitas Belajar terhadap Prestasi Belajar Mata Pelajaran Ekonomi pada Siswa Kelas XI IPS SMA Negeri 1.” Jurnal Pendidikan Insan Mandiri, 1(1), 1-13. Retrieved from http:// jurnal.fkip.uns.ac.id/index.php/s2ekonomi/ article/view/1899.

Kovač, V., Rafajac, B., \& Buchberger, I. (2014). "Croatian Teacher Competencies Related to the Creation and Implementation of Education Policy." C.E.P.S Journal, 4(4), 51-73.

Libânio, C. D. S., Amaral, F. G., \& Migowski, S. A. (2017). "Classification of Competencies in Design Management: Individual, Collective and Organizational Levels." Strategic Design Research Journal, 10(3), 195-203. https://doi. org/10.4013/sdrj.2017.103.01.
Maharoh, E. (2005). Persepsi Masyarakat terhadap Profesionalitas Guru Pasca Sertifikasi. Jurnal Ilmiah PPKN IKIP Veteran Malang, (20), 21-32.

McClelland, D. C. (1973). "Testing for Competence rather than for Intelligence" "The American Psychologist, 28(1), 1-14. https://doi. org/10.1037/h0034092.

McClelland, D. C. (1998). "Identifying Competencies with Behavioral Event Interviews." Psychological Science, 9(5), 331-339. https://doi.org/ $10.1111 / 1467-9280.00065$.

Novauli, Feralys. (2012). "Pengaruh Kompetensi Guru terhadap Peningkatan Prestasi Belajar pada SMP Negeri di Kota Banda Aceh," Jurnal Pencerahan Vol 6(1) Maret 2012. Hlm. 17-32.

Prasojo, L. D., Wibowo, U. B., \& H, A. D. (2017). "Manajemen Kurikulum Program Profesi Guru untuk Curriculum Management of Teacher Professional Program for Frontier, Outermost, and Least Developed Regions." Jurnal Pendidikan Dan Kebudayaan, 2(1), 39-53.

Sammons, P., \& Bakkum, L. (2011). "Effective Schools, Equity and Teacher Effectiveness: A Review to the Literature." Profesorado, 15(3), 9-26. Retrieved from http://www.ugr. es/ recfpro/rev153ART2en.pdf.

Sobandi, A. (2010). "Pengaruh Kompetensi Guru terhadap Kinerja Mengajar Guru SMKN Bidang Keahlian Bisnis dan Manajemen di Kota Bandung." Jurnal Manajerial, 9, 25-34.

Soemantri, Hermana.(2010). "Kompetensi Sebagai Landasan Konseptual Kebijakan Kurikulum Sekolah di Indonesia." Jurnal Pendidikan dan Kebudayaan, Vol. 16, Nomor 6, November 2010.

Sutardi, S., \& Sugiharsono, S. (2016). "Pengaruh Kompetensi Guru, Motivasi Belajar, dan Lingkungan Keluarga Terhadap Hasil Belajar Mata Pelajaran Ekonomi." Harmoni Sosial: Jurnal Pendidikan IPS, 3(2), 188-198.

Suratno, T. (2011). "The Education System in Indonesia at a Time of Significant Changes." Revue Internationale d'éducation de Sèvres, 58(décembre 2011), 12-15. Retrieved from http://ries.revues.org/2131.

\section{Buku}

Hurlock, E. B.(1976). Perkembangan Anak Jilid 2, Edisi Keenam. Jakarta: Penerbit Erlangga. 
Mudhofir, Ali.(2012). Pendidik Profesional: Konsep, Strategi, dan Aplikasinya dalam Peningkatan Mutu Pendidikan Di Indonesia. Jakarta: Raja Grafindo Persada. ISBN 9789797694630.

Sardiman, A.M.(2005). Interaksi dan Motivasi Belajar Mengajar. Jakarta: Raja Grafindo.

Spencer, Lyle \& Spencer, Signe M. (1993). Competence at Work, Models For Superior Performance. Canada : John Wiley \& Sons, Inc.

Susanto, Ahmad.(2016). Konsep, Strategi, dan Implementasi Manajemen Peningkatan Kinerja Guru. Jakarta: Prenadamedia Group.

\section{Skripsi}

Azzahra, Aroma Fatima. (2015). "Pengaruh Kompetensi Guru terhadap Hasil Belajar Siswa pada Mata Pelajaran Ilmu Pengetahuan Sosial di SMP Plus Al-Kautsar Blimbingan Malang." Skripsi, tidak diterbitkan. http://etheses.uinmalang.ac.id/3108/1/11130078.pdf.

\section{Internet}

Sri Mulyani Sindir Tunjangan Guru: Besar tapi Tak Berkualitas, https://bisnis. tempo.co/ $\mathrm{read} / 1105459 /$ sri-mulyani-sindir-tunjanganguru-besar-tapi-tak-berkualitas, diakses 17 September 2018.

Teacher-certification-competency-detraction, http:// www.thejakarta post.com/news/ 2015/ 03/14/ teacher-certification-competency-detraction. html, diakses tanggal 20 Mei 2018.

\section{Laporan}

Advisory Committee on Teacher Education and Qualifications. (2003). Towards a Learning ProfessionThe TeacherCompetenciesFramework and The CPD of Teachers, 1-51. https://doi. org/10.1017/CBO9781107415324.004.

Dirjen Peningkatan Mutu Pendidik dan Tenaga Kependidikan. (2010). Pedoman Pelaksanaan Penilaian Kinerja Guru. Jakarta.

Ismail, Tengku. (2018, 25 September). Paparan Dirjen GTK, disampaikan dalam Seminar Nasional Urgensi Perubahan Undang-Undang NO 14 Tahun 2005 tentang Guru dan Dosen, Jakarta.

Larsson, M. (2004). The INNOMET Taxonomy of Competences and Skills, 1-22.
Listyarti, Retno. (2018, 26 Juli). Trend Masalah Pendidikan Dari Perspektif Perlindungan Anak di Indonesia, disampaikan dalam FGD Mencari Solusi Permasalahan Pendidikan Nasional, Jakarta.

Kantor Staf Presiden Republik Indonesia. (2017). Kajian Anggaran Pendidikan. Tidak diterbitkan.

Kementerian Pendidikan dan Kebudayaan. (2017). Rangkuman Statistik Persekolahan 2017/2018 (edisi Revisi). Jakarta: Setjen, Kemendikbud.

Kementerian Pendidikan dan Kebudayaan. (2016). Analisis Sumber Daya Manusia Pendidikan Dasar dan Menengah 2015/2016. Jakarta.

Direktorat Tenaga Kependidikan. (2008). Penilaian Kinerja Guru. Jakarta: Departemen Pendidikan Nasional.

OECD. (2003). The definition and selection of key competencies - Executive summary. DeSeCo. https://doi.org/10.1080/2159676X.2012.712997.

Direktorat Jenderal Guru Dan Tenaga Kependidikan. (2015). Pedoman Pelaksanaan Uji Kompetensi Guru. Jakarta: Kementerian Pendidikan dan Kebudayaan.

Pusat Perancangan Undang-Undang. (23 Juli 2018). Laporan Pengumpulan Data ke UPI Bandung. Jakarta: Badan Keahlian DPR RI, tidak diterbitkan.

PISA.(2014). PISA 2012 Results in Focus What 15 -year-olds know and what they can do with what they know.OECD.

Putusan MK Nomor 6/PUU-XV/2017.

UNESCO. (2011). ICTs and Teacher Competencies, (66), 124-125. https://doi. org/10.1177/0022146513479002.

Kementerian Pendidikan dan Kebudayaan, The World Bank, \& Australian Aid. (2014). Sistem Pendidikan Tinggi Indonesia : Seberapa Responsif Terhadap Pasar Kerja? (No. 89222). Jakarta. 